\title{
Influence of copper mine on surface water quality
}

\author{
G. R. Nabi Bidhendi, A. R. Karbassi, ${ }^{*}$ T. Nasrabadi, H. Hoveidi
}

\author{
Graduate Faculty of the Environment, Tehran University, Tehran, Iran
}

Received 27 September 2006; revised 20 October 2006; accepted 28 November 2006; available online 1 January 2007

\begin{abstract}
Aras water basin is located in northwest of Iran. Sungun mine which is the largest open-cast copper mine of Iran is located in this region and is in the primary stages of extraction. The influence of mining activity on the quality of regional surface water has been taken in to consideration in this study. Accordingly, sampling was done from 5 local streams in the study area. In order to consider the effect of flow quantity on the amount of different parameters, sampling was done in July and November 2005 when the local streams had the minimum and maximum flow rate respectively. The concentrations of major anions and cations as well as $\mathrm{As}, \mathrm{Mo}, \mathrm{Al}, \mathrm{Cu}, \mathrm{Cd}, \mathrm{Cr}, \mathrm{Fe}, \mathrm{Mn}$ and $\mathrm{Zn}$ were determined. The results showed that the concentrations of metallic ions like aluminum, chromium, copper, manganese, molybdenum and iron in samples collected in July are above USEPA (Environmental Protection Agency) limits; however, mentioned concentrations are lessened remarkably in the samples collected in November. This fact is justified considering dilution of ions concentration via more amount of water in November. The chemical characteristics of water compositions on the basis of major ion concentrations were evaluated on a Schoeller and Piper diagram. Accordingly, the dominant type of water in July and November is considered to be $\mathrm{Ca}-\mathrm{HCO}_{3}$ (calcium-bicarbonate type). Regarding Schoeller diagram, despite relatively high concentration of calcium, the current status of local surface water is acceptable for drinking purposes. By commencing mining excavation with designed capacity in near future, the minerals will come in to contact with air and water resulting in dissolution, especially in ponds, which, in turn, increases the concentration of heavy metals in surface water. Considering consequent uses of this water including drinking, irrigation, industrial, etc. precautions must be taken in to consideration.
\end{abstract}

Key words: Sungun copper mine, surface water pollution, water quality

\section{INTRODUCTION}

Aras water catchment is located in northwest of Iran. Existence of metallic minerals in geological textile of the region is widely observed. Sungun copper mine which is located in $38^{\circ} 38^{\prime} 20^{\prime \prime}$ north latitude and $46^{\circ} 45^{\prime} 35^{\prime \prime}$ east longitude is the most important geologic and industrial feature in the area. Containing more than 388 million tons of copper ore with the average content of $63 \%$, Sungun mine is the largest open-cast copper mine in Iran and is in the primary stages of extraction. The location of Sungun copper mine in Iran is shown in Figs. 1. Under groundwater resources in the region is the main back up of the flow within catchment's streams and consequently in Aras River. Accordingly, monitoring the quality of water in this stage will be the first option. Aras river as one of the largest rivers in the country is the common boundary between Iran and Azerbaijan in a large distance and finally reaches

\footnotetext{
*Corresponding author, Email: t_nasrabadi@yahoo.com Tel.: +9821-6640 7719; Fax: +9821-6640 4647
}

to Caspian Sea. This river supplies potable water to tens of cities and villages, irrigation water to thousands of hectares of irrigation land, water to fish husbandry projects and water to numerous industrial units. Despite increased awareness of the potential threats to the environment, there are many areas around the world where pollution from mining operations is still taking place (Alderton, et al., 2005). Mining activities always impact environmental quality (Vertanyan 1989; Eggert 1994; Ripley, et al., 1996; Lottermoser, et al., 1999; Gabler and Schneider 2000; Marszalek and Wasik 2000). Intensive mining activities have resulted in significant deterioration of water and terrestrial ecosystems in the vicinity of the mines (Malinovsky, et al., 2002). The degree of impact depends on many factors, in particular, mining type and the size of the operation. A mining activity mainly disturbs and changes the topography of land; ultimately adversely affects the hydrogeologic conditions (Bell, et al., 2000). Heavy metals, one of 
the most important water quality parameters, may also get enriched in water because of mining activities (Prasad and Bose, 2001). Weathering of mine waste piles can increase concentrations of toxic elements downstream from the mine site as reduced phases in their host minerals oxidize (Lottermoser and others 1999; Munroe and others 1999; Banwart and Malmstrom 2001; Baba and Gungor 2002). In addition to the high content of trace metals in ore deposits, their background concentration in a regional or district scale is commonly higher than the universal values and it can also release elements to the environment. Despite the mineral wealth and importance of exploration and mining in Iran, there is virtually no record of the environmental geochemistry or studies of the general environmental impact of Iranian ore deposits or mine sites. (Modabberi, et al., 2004). The objective of this study is to investigate the possibility of adverse effects of mining copper deposit around the mentioned study area on the surface water quality.

\section{Geology of the mining area}

The mineralization is largely hosted by a hydrothermally altered quartz-monzonite porphyry intrusion, which forms part of the Sungun Stock. Feldspar, which comprises $30 \%$ of the rock mass, is largely altered to sericite or kaolin. Later silicification, when intensely developed, resulted in the loss of the original porphyritic texture to produce a more compact rock with cross cutting quartz veins, commonly associated with pyrite, molybdenite and, more rarely, chalcopyrite. The copper and molybdenum grade of the deposit increase steadily with depth, particularly in the hypogene zone.

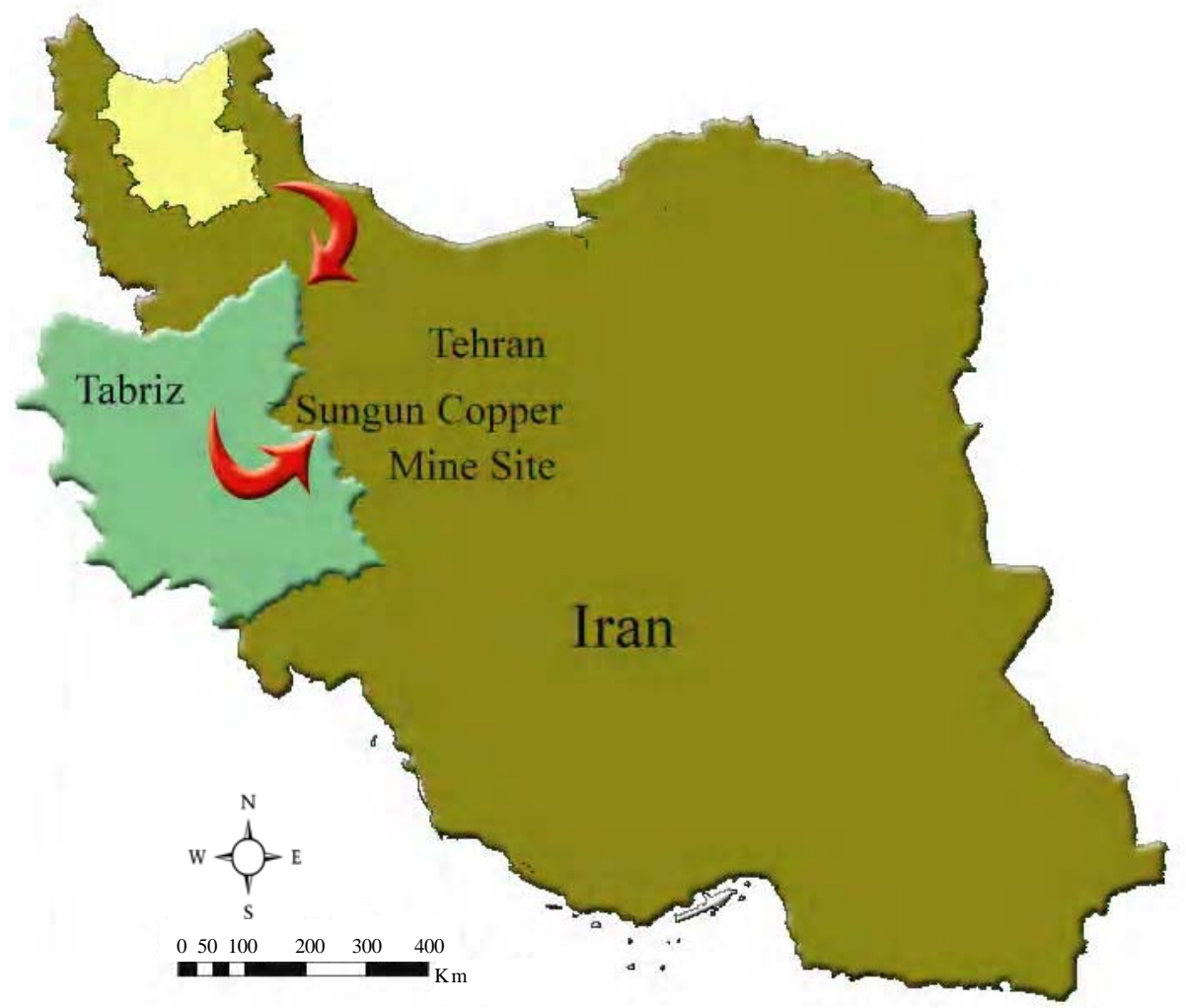

Fig. 1: Location map of Sungun copper mine in Iran 


\section{MATERIALS AND METHODS}

This study comprises a specific part of Aras river watershed surrounding Sungun copper mine. Site visits and review of the existing data was the first step followed by identifying major source of pollution and collecting its qualitative parameters and data analysis. Therefore site visits were made in order to recognize sampling stations. Accordingly, 22 springs were defined as stations all around the study area. Nature of the examined parameters was selected based on the consequences of mining activities and geologic textile of the area. Accordingly parameters like $\mathrm{pH}$, dissolved oxygen (DO), electrical conductivity (EC), total dissolved solids (TDS), Anions like bicarbonate, sulfate and cations like $\mathrm{Na}, \mathrm{K}, \mathrm{Ca}, \mathrm{Mg}, \mathrm{Al}, \mathrm{Fe}, \mathrm{Mn}, \mathrm{Cr}$, $\mathrm{Cu}, \mathrm{Cd}, \mathrm{Mo}, \mathrm{Pb}$ and $\mathrm{Zn}$ were taken in to consideration. In order to consider the effect of flow quantity on the amount of different parameters, sampling was done in July and November 2005 when the local streams had the minimum and maximum flow rate respectively. Dissolved Oxygen (DO), pH, temperature and EC were measured in-situ. For sample collection, $500 \mathrm{cc}$ polyethylene bottles were rinsed three times with the river water before being filled. The water samples for analysis of metals were immediately acidified with $1 \%$ Merck quality nitric acid. For analysis of anions, another bottle was filled in each station in the same manner but not acidified. Anion concentrations has been measured using HACH DR/2000 in the hydro chemical laboratory of Tehran University, cations also were measured there using ICP-MS according to EPA-3005 method.

\section{RESULTS}

Field parameters (pH, DO and EC), and the results of major anion and cation analysis of the samples collected in July and November are presented in Tables $1,2,3$ and 4 as well as the results for mentioned trace elements. Comparison between the results of tables relating to collected samples in July and November indicates that the concentration of most metallic ions shows a remarkable decrease in November, when the flow rate is in its maximum state. This fact is justified considering dilution of ions concentration via more amount of water in November

\section{Quality of waters}

The chemical characteristics of water compositions on the basis of major ion concentrations were evaluated on a Schoeller and Piper diagram (Figs. 3, 4, 5 and 6$)$.

By evaluating the concentration of major elements, it is seen that the dominant type of water in the region is considered to be $\mathrm{Ca}-\mathrm{HCO}_{3}$ (calcium- bicarbonate type).

Table 1: Results of physical and chemical characteristics of surface water samples (Sampling: July 2005)

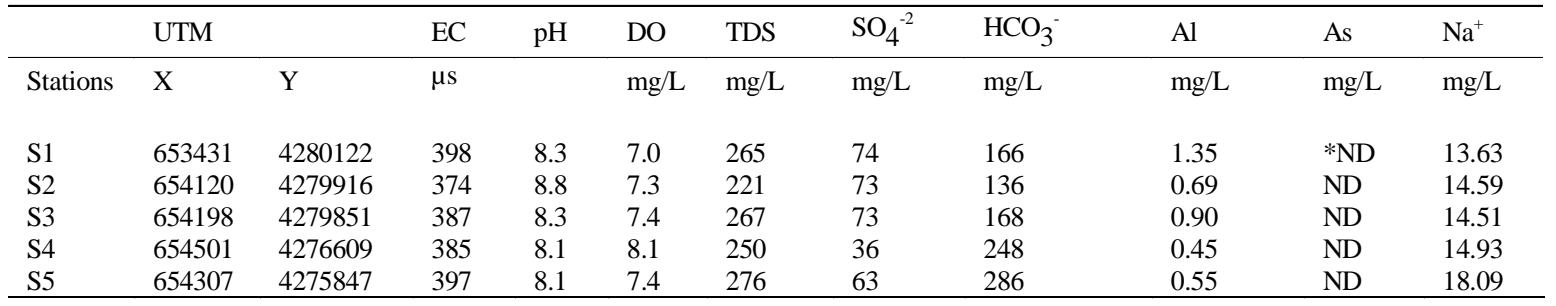

$\mathrm{ND}=$ Not Detected *

Table 2: Results of metallic ions concentrations in surface water samples (Sampling: July 2005)

\begin{tabular}{|c|c|c|c|c|c|c|c|c|c|c|c|}
\hline & $\mathrm{Cd}$ & $\mathrm{Cr}$ & $\mathrm{Cu}$ & $\mathrm{Fe}$ & $\mathrm{K}^{+}$ & Mn & Mo & $\mathrm{Pb}$ & $\mathrm{Zn}$ & $\mathrm{Ca}^{2+}$ & $\mathrm{Mg}^{2+}$ \\
\hline Stations & $\mathrm{mg} / \mathrm{L}$ & $\mathrm{mg} / \mathrm{L}$ & $\mathrm{mg} / \mathrm{L}$ & $\mathrm{mg} / \mathrm{L}$ & $\mathrm{mg} / \mathrm{L}$ & $\mathrm{mg} / \mathrm{L}$ & $\mathrm{mg} / \mathrm{L}$ & $\mathrm{mg} / \mathrm{L}$ & $\mathrm{mg} / \mathrm{L}$ & $\mathrm{mg} / \mathrm{L}$ & $\mathrm{mg} / \mathrm{L}$ \\
\hline S1 & ND & 0.41 & 0.85 & 1.50 & 17.65 & 0.56 & 1.21 & 0.01 & 1.5 & 128.31 & 12.01 \\
\hline S2 & ND & 0.40 & 1.03 & 0.86 & 14.81 & 0.63 & 0.84 & ND & 1.46 & 80.33 & 9.83 \\
\hline S3 & ND & 0.39 & 0.74 & 0.98 & 16.96 & 0.42 & 0.90 & ND & 1.42 & 136.43 & 12.20 \\
\hline S4 & ND & 0.39 & 0.55 & 0.65 & 3.51 & 0.38 & 0.89 & 0.01 & 1.45 & 147.82 & 11.76 \\
\hline S5 & ND & 0.39 & 0.51 & 0.62 & 4.28 & 0.54 & 0.22 & ND & 1.29 & 163.84 & 12.45 \\
\hline
\end{tabular}


Influence of copper mine on surface water quality

Table 3: Results of physical and chemical characteristics of surface water samples (Sampling: Nov. 2005)

\begin{tabular}{|c|c|c|c|c|c|c|c|c|c|c|c|}
\hline & UTM & & EC & $\mathrm{pH}$ & DO & TDS & $\mathrm{SO}_{4}{ }^{2-}$ & $\mathrm{HCO}_{3}^{-}$ & $\mathrm{Al}$ & As & $\mathrm{Na}^{+}$ \\
\hline Stations & $\mathrm{X}$ & $\mathrm{Y}$ & $\mu \mathrm{s}$ & & $\mathrm{mg} / \mathrm{L}$ & $\mathrm{mg} / \mathrm{L}$ & $\mathrm{mg} / \mathrm{L}$ & $\mathrm{mg} / \mathrm{L}$ & $\mathrm{mg} / \mathrm{L}$ & $\mathrm{mg} / \mathrm{L}$ & $\mathrm{mg} / \mathrm{L}$ \\
\hline S1 & 653431 & 4280122 & 621 & 8.9 & 7.0 & 311 & 81 & 168 & 0.93 & ND & 22.27 \\
\hline S3 & 654198 & 4279851 & 595 & 8.3 & 6.8 & 419 & 80 & 144 & 0.48 & ND & 17.33 \\
\hline S4 & 654501 & 4276609 & 567 & 8.2 & 7.1 & 284 & 54 & 200 & 0.24 & ND & 23.36 \\
\hline S5 & 654307 & 4275847 & 531 & 8.4 & 6.7 & 265 & 75 & 184 & 0.18 & ND & 18.42 \\
\hline
\end{tabular}

Table 4: Results of metallic ions concentrations in surface water samples (Sampling: Nov. 2005)

\begin{tabular}{|c|c|c|c|c|c|c|c|c|c|c|c|}
\hline & $\mathrm{Cd}$ & $\mathrm{Cr}$ & $\mathrm{Cu}$ & $\mathrm{Fe}$ & $\mathrm{K}^{+}$ & Mn & Mo & $\mathrm{Pb}$ & $\mathrm{Zn}$ & $\mathrm{Ca}^{2+}$ & $\mathrm{Mg}^{2+}$ \\
\hline Stations & $\mathrm{mg} / \mathrm{L}$ & $\mathrm{mg} / \mathrm{L}$ & $\mathrm{mg} / \mathrm{L}$ & $\mathrm{mg} / \mathrm{L}$ & $\mathrm{mg} / \mathrm{L}$ & $\mathrm{mg} / \mathrm{L}$ & $\mathrm{mg} / \mathrm{L}$ & $\mathrm{mg} / \mathrm{L}$ & $\mathrm{mg} / \mathrm{L}$ & $\mathrm{mg} / \mathrm{L}$ & $\mathrm{mg} / \mathrm{L}$ \\
\hline S1 & 0.13 & 0.06 & 0.01 & 0.70 & 35.53 & 0.06 & 0.04 & ND & 0.19 & 300.01 & 19.36 \\
\hline S2 & ND & 0.04 & ND & 0.25 & 36.10 & 0.03 & 0.04 & 0.06 & 0.07 & 367.39 & 20.00 \\
\hline S3 & 0.02 & 0.07 & ND & 0.47 & 23.65 & 0.18 & 0.05 & ND & 0.11 & 41.88 & 25.41 \\
\hline S4 & ND & 0.05 & ND & 0.18 & 3.84 & ND & 0.03 & ND & 0.05 & 357.71 & 18.40 \\
\hline S5 & ND & 0.04 & ND & 0.18 & 3.97 & ND & 0.04 & ND & 0.17 & 288.50 & 16.64 \\
\hline
\end{tabular}

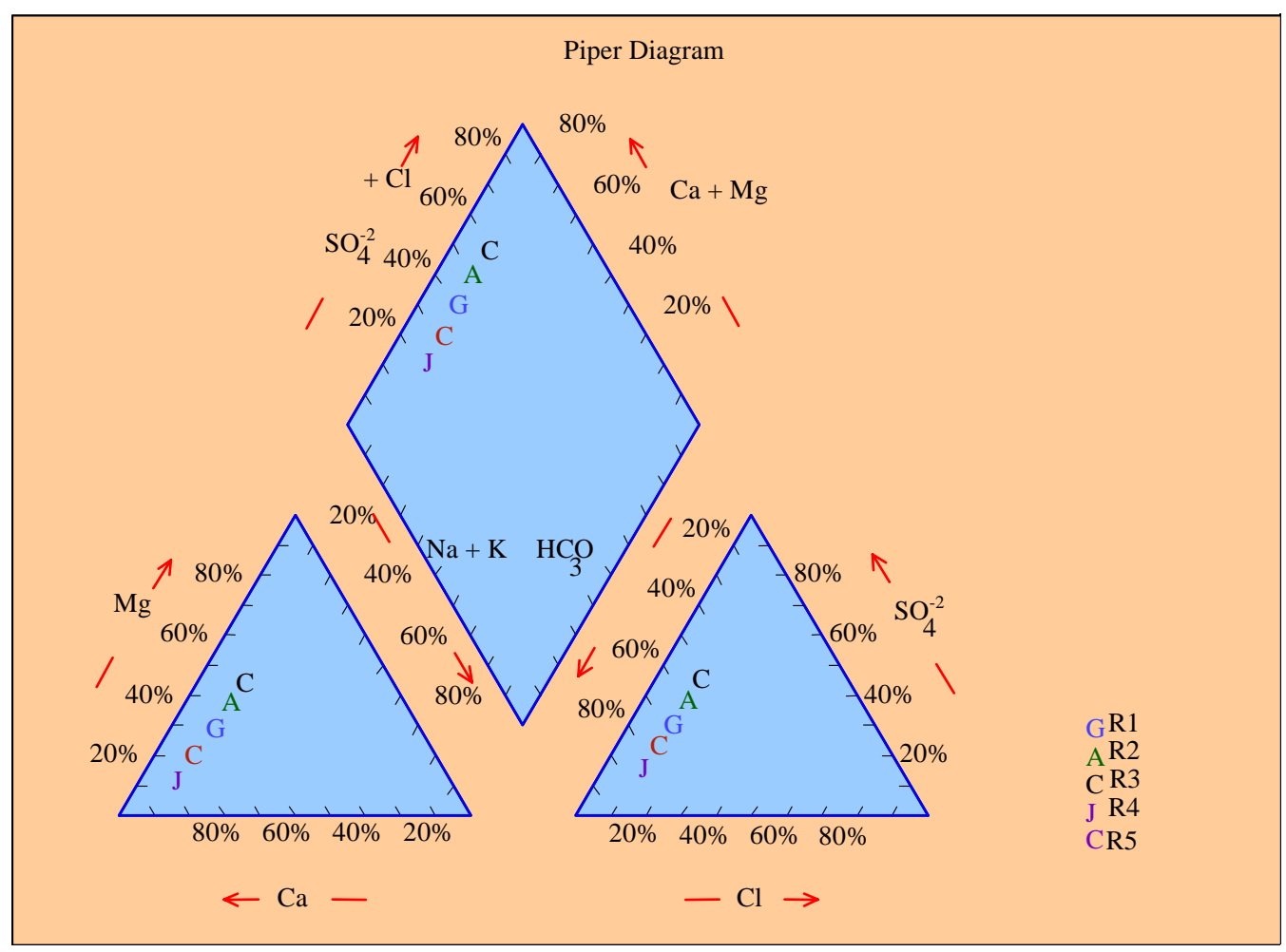

Fig. 3: Piper diagram showing the chemical compositions of surface water (Nov. 2005) 
Int. J. Environ. Sci. Tech., 4 (1): 85-91, 2007

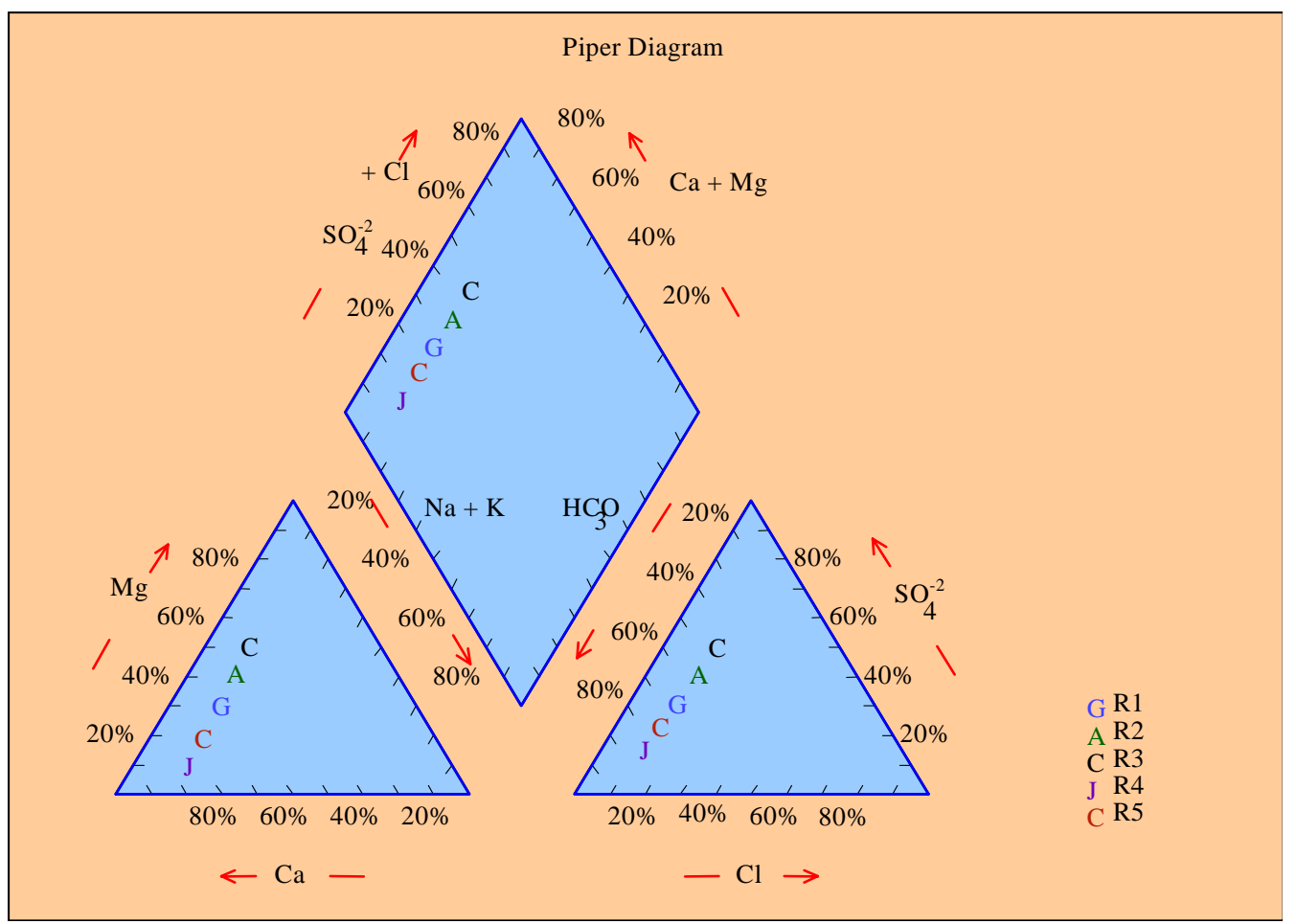

Fig. 4: Piper diagram showing the chemical compositions of surface water (July 2005)

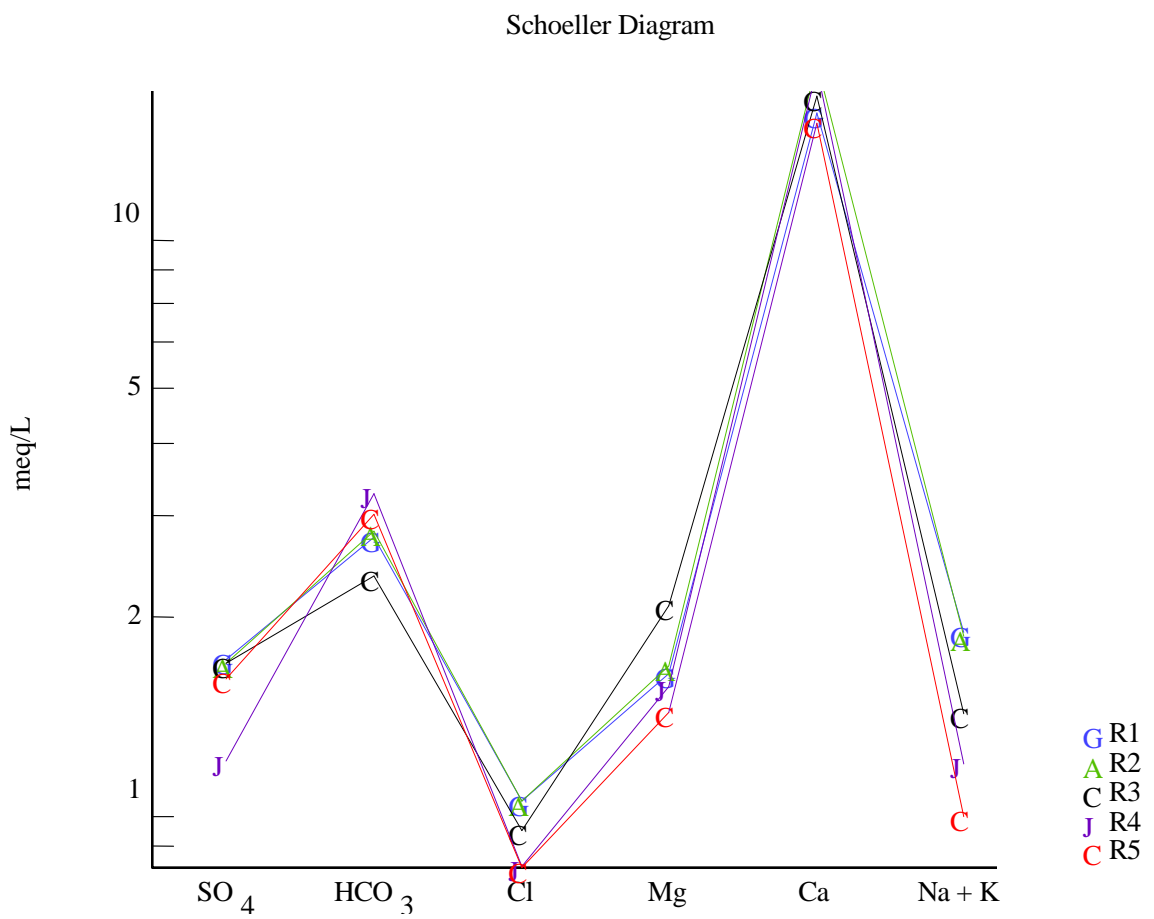

Fig. 5: Chemical analysis of surface water of the study area plotted on the Schoeller diagram (Nov. 2005) 
G.R. Nabi Bidhendi, et al.

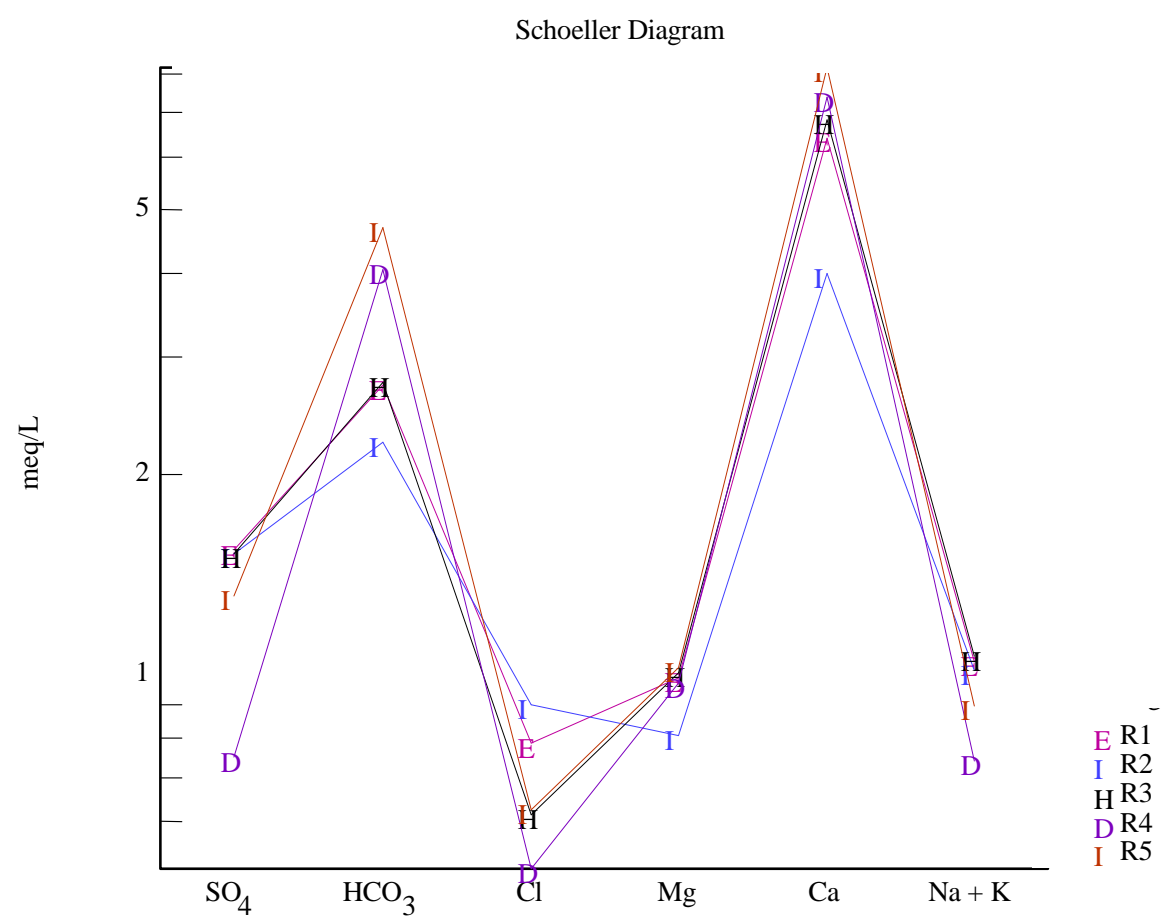

Fig. 6: Chemical analysis of surface water of the study area plotted on the Schoeller diagram (July 2005)

A strong convergence between the results in July and November is also observed. Regarding Schoeller diagram, despite relatively high concentration of calcium, the current status of local surface water in both months is acceptable for drinking purposes.

\section{DISCUSSION AND CONCLUSION}

The concentrations of $\mathrm{Al}, \mathrm{Cu}, \mathrm{Cd}, \mathrm{Cr}, \mathrm{Fe}, \mathrm{Pb}, \mathrm{Mn}$, $\mathrm{Zn}, \mathrm{Mo}, \mathrm{Pb}$ and other major cations and anions are compared with the limits established by the United States Environmental Protection Agency (USEPA). Such a comparison shows that the concentrations of metallic ions like aluminum, chromium, copper, manganese, molybdenum and iron in samples collected in July are above USEPA limits; however, mentioned concentrations are lessened remarkably in the samples collected in November. This fact is justified considering dilution of ions concentration via more amount of water in November. It should, therefore, be stated that the concentrations of the major anions and cations, especially heavy metals are high in the vicinity of ore bodies. This increase is justified by local mining activities which terminate in more contact of minerals with water and air. Furthermore, the pHs of water samples are within the allowable ranges. Mining site is not still formally inaugurated and mining excavation is still in its first stages. By commencing mining excavation with designed capacity in near future, the minerals will come in to contact with air and water resulting in dissolution, especially in ponds, which, in turn, increases the concentration of heavy metals in surface water. On the other hand, the surface water of the area is used for purposes like drinking and irrigation potable without any treatment. Therefore precise monitoring of water resources of the region is very important considering the health of people and other organisms in downstream.

\section{REFERENCES}

Alderton, D.H.M., Serafimovski, T., Mullen, B., Fairall, K., James, S., (2005), The chemistry of waters associated with metal mining in Macedonia, Mine, Water and the Environment, 24, (3), 139-149.

Baba, A., Gungor, T., (2002). Influence of gold mine on groundwater quality (Efemcukuru, Izmir, Turkey). Environ. Geo., 41, 621-627.

Banwart, S.A., Malmstrom, M.E., (2001). Hydrochemical modelling for preliminary assessment of minewater pollution. J. Geochem. Explor., 74, 73-97.

Bell, F.G., Stacey, T.R., Genske, D.D., (2000). Mining subsidence and its effect on the environment : some differing examples. Environ. Geo., 40 (1-2), 135-152.

Eggert, R.G., (1994). Mining and the environment: an intro- 
-duction and overview. In: Eggert RG (ed) Mining and the environment: international perspectives on public policy. Resources for the future (REF). Washington, DC., 1-20.

Gabler, H.E., Schneider, J., (2000). Assessment of heavy-metal contamination of floodplain soils due to mining and mineral processing in the Harz mountains, Germany. Environ. Geo., 39 (7), 774-782.

Lottermoser, B.G., Ashley, P.M., Lawie, D.C., (1999). Environmental geochemistry of the Gulf Creek copper mine area, north-eastern New South Wales, Australia. Environ. Geo. 39 (1), 61-74.

Malinovsky, D., Rodushkin, I., Moiseenko, T., Ohlander, B., (2002), Aqueous transport and fate of pollutants in mining area: a case study of Khobiny apatite-nepheline mines, the Kola Peninsula, Russia. Environ. Geo., 43, (1-2), 172-187. Marszalek, H., Wasik, M., (2000). Influence of arsenic- bearing gold deposits on water quality in Zloty Stok mining area (SW Poland). Environ. Geo., 39 (8), 888-892.
Modabberi, S., Moore, F., (2004), Environmental geochemistry of Zarshuran Au-As deposit, NW Iran, Environ. Geo., 46, (6-7), 796-807.

Munroe, E.A., McLemore, V.T., Kyle, P., (1999). Waste rock pile characterization, heterogeneity, and geochemical anomalies in the Hillsboro Mining District, Sierra County, New Mexico., J. Geochem. Explor., 67, 391-405.

Prasad, B., Bose, J.M., (2001), Evaluation of the heavy metal pollution index for surface and spring water near a limestone mining area of the lower Himalayas, Environ, Geo., 41, (12), 183-188.

Ripley, E.A., Redmann, R.E., Crowder, A.A., (1996) Environmental effects of mining. St. Lucie Press, Delray Beach, Florida.

Santos, A., Alonso, E., Callejon, M., Jimenez, J.C., (2002) Distribution of $\mathrm{Zn}, \mathrm{Cd}, \mathrm{Pb}$ and $\mathrm{Cu}$ metals in groundwater of the Guadiamar river basin, Wat., Air, Soil, Poll, 134 (1-4), 273-283.

\section{AUTHOR (S) BIOSKETCHES}

Nabi Bidhendi, Gh., Ph.D., is a associate professor in the Graduate Faculty of Environment, University of Tehran, Tehran, Iran. Email: ghhendi@ut.ac.ir

Karbassi, A.R., Ph.D., is an assisstant professor in the Graduate Faculty of Environment, University of Tehran, Tehran, Iran. Email: karbassi@iranenergy.org.ir

Nasrabadi, T., P.hD. student in environmental engineering at the Graduate Faculty of Environment, University of Tehran. Tehran, Iran. Email: t_nasrabadi@yahoo.com

Hoveidi, H., M.Sc. in environmental management at the Graduate Faculty of Environment, University of Tehran. Tehran, Iran. Email: hoveidi10@yahoo.com

This article should be referenced as follows:

Nabi Bidhendi, Gh., Karbassi, A.R., Nasrabadi, T., Hoveidi, H., (2007). Influence of copper mine on surface water quality, Int. J. Environ. Sci. Tech., 4 (1), 85-91. 